15. Hausman, J. F., Evers, D., Thiellement, H. and Jouve, L., Compared responses of poplar cuttings and in vitro raised shoots to shortterm chilling treatments. Plant Cell Rep., 2000, 19, 954-960.

16. Gindl, W., Grabner, M. and Wimmer, R., The influence of temperature on latewood lignin content in treeline Norway spruce compared with maximum density and ring width. Trees-Struct. Funct., 2000, 14, 409-414.

17. Weng, J. K. and Chapple, C., The origin and evolution of lignin biosynthesis. New Phytol., 2010, 187, 273-285.

18. Rogers, L. A. and Campbel, M. M., The genetic control of lignin deposition during plant growth and development. New Phytol., 2004, 164, 17-30.

19. Olenichenko, N. and Zagoskina, N., Response of winter wheat to cold: production of phenolic compounds and 1-phenylalanine ammonia lyase activity. Appl. Biochem. Microbiol., 2005, 41, 600-603.

20. Janas, K. M., Cvikrova, M., Palagiewicz, A. and Eder, J., Alterations in phenylpropanoid content in soybean roots during low temperature acclimation. Plant Physiol. Biochem., 2000, 38, 587-593.

21. EI Kayal, W., Keller, G., Debayles, C., Kumar, R., Weier, D., Teulieres, C. and Marque, C., Regulation of tocopherol biosynthesis through transcriptional control of tocopherol cyclase during cold hardening in Eucalyptus gunnii. Physiol. Plantarum., 2006, 126, 212-223.

22. MacDonald, M. J. and D'Cunha, G. B., A modern view of phenylalanine ammonia lyase. Biochem. Cell Biol., 2007, 85, 273-282.

23. Valiñas, M. A., Lanteri, M. L., ten Have, A. and Balbina Andreu, A., Chlorogenic acid biosynthesis appears linked with suberin production in potato tuber (Solanum tuberosum). J. Agric. Food Chem., 2015, 63(19), 4902-4913.

24. Hisano, H., Nandakumar, R. and Wang, Z. Y., Genetic modification of lignin biosynthesis for improved biofuel production. In vitro Cell. Dev. Biol. (Plant), 2009, 45, 306-313.

25. $\mathrm{Hu}, \mathrm{R}$. et al., Comparative transcriptome analysis revealed the genotype specific cold response mechanism in tobacco. Biochem. Biophys. Res. Commun., 2016, 469(3), 535-541.

26. Wagner, A. et al., CCoAOMT suppression modifies lignin composition in Pinus radiata. Plant J., 2011, 67, 119-129.

27. Guo, D., Chen, F., Inoue, K., Blount, J. W. and Dixon, R. A., Downregulation of caffeic acid 3-O-methyltransferase and caffeoyl CoA 3-O-methyltransferase in transgenic alfalfa: impacts on lignin structure and implications for the biosynthesis of $\mathrm{G}$ and $\mathrm{S}$ lignin. Plant Cell Online, 2001, 13, 73-88.

28. Guo, D., Chen, F., Wheeler, J., Winder, J., Selman, S., Peterson, M. and Dixon, R. A., Improvement of in-rumen digestibility of alfalfa forage by genetic manipulation of lignin $O$-methyltransferases. Transgenic Res., 2001, 10, 457-464.

29. Zhong, R., Morrison, W. H., Himmelsbach, D. S., Poole, F. L. and Ye, Z. H., Essential role of caffeoyl coenzyme A $O$ methyltransferase in lignin biosynthesis in woody poplar plants. Plant Physiol., 2000, 124, 563-578.

30. Bonawitz, N. D. and Chapple, C., The genetics of lignin biosynthesis: connecting genotype to phenotype. Ann. Rev. Genet., 2010, 44(1), 337-363.

31. dos Santos, A. B. et al., Lignin biosynthesis in sugarcane is affected by low temperature. Environ. Exp. Bot., 2015, 120, 31-42.

ACKNOWLEDGEMENTS. This study was supported by the Fundamental Research Funds for Central Non-Profit Scientific Institution (1610232016019), Longyan Corporation of Fujian Tobacco Corporation (LYK201302), and the Agricultural Science and Technology Innovation Program (ASTIP-TRIC03).

Received 2 August 2018; revised accepted 5 August 2019

doi: $10.18520 / \mathrm{cs} / \mathrm{v} 117 / \mathrm{i} 11 / 1885-1892$

\section{The Sandan slot canyon in the Deccan Traps: its morphology and mode of origin}

\author{
Pramodkumar S. Hire ${ }^{1, *}$, Archana D. Patil ${ }^{2}$ and \\ Vishwas S. Kale ${ }^{3}$
}

${ }^{1}$ Department of Geography, HPT Arts and RYK Science College, Nashik 422 005, India

${ }^{2}$ Department of Geography, RNC Arts, JDB Commerce and NSC Science College, Nashik 422 101, India

${ }^{3}$ A6 Manmohan Society, Karvenagar, Pune 411 052, India

Slot canyons, with extremely small width-depth ratios, are rare geomorphic features that develop under limited range of fluvial conditions. We report the occurrence of such an uncommon canyon, developed on the crest of the Western Ghats in the Deccan Traps. The canyon is a tourist hotspot. Geomorphic studies reveal that the Sandan slot canyon is $2-30 \mathrm{~m}$ wide and up to $100 \mathrm{~m}$ deep. Based on compelling field evidence we hypothesize that the morphology of the slot canyon is the product of the interplay between flash flood-induced excavation of a dyke and slope failures.

Keywords. Dyke, flash flood, slot canyon, slope failure.

GORGES are one of the most common erosional sculpted forms in actively incising fluvial landscapes around the world. In comparison, extremely narrow, deep and slotlike bedrock gorges, commonly called slot canyons ${ }^{1}$, are rare and develop under limited range of fluvial conditions. Slot canyons have very small width-depth ratios (depth $\geq$ width) and the canyon walls make up a larger proportion of the channel boundary or perimeter than the canyon bottom (base) ${ }^{1}$. Majority of the slot canyons documented in the geomorphic literature occur in southwest $\mathrm{USA}^{2}, \mathrm{China}^{3}$ and Austria ${ }^{4}$ in a variety of rocks (sandstone, conglomerate, granite, gneiss, basalt, etc.). Till date, slot canyons have not been documented in the Indian subcontinent.

Here we report the occurrence and geomorphic characteristics of such an uncommon slot canyon from the Deccan Traps. The roughly north-south-oriented Sandan slot canyon (SSC) developed in compound lava flows is situated near Samrad village $\left(19^{\circ} 30^{\prime} 46^{\prime \prime} \mathrm{N}\right.$ and $\left.73^{\circ} 41^{\prime} 11^{\prime \prime} \mathrm{E}\right)$ (Figure $1 a$ ) in Ahmednagar district, Maharashtra, India ${ }^{5}$ and occurs on the crest of the Western Ghats Escarpment (Figure $1 b$ ). The canyon is a popular tourist hot spot and is famous for exhilarating adventure sports such as giant swing, rappelling and flying fox.

The main objectives of this study are: (a) to document the downstream variations in the canyon morphology, and

*For correspondence. (e-mail: pramodkumarhire@gmail.com) 


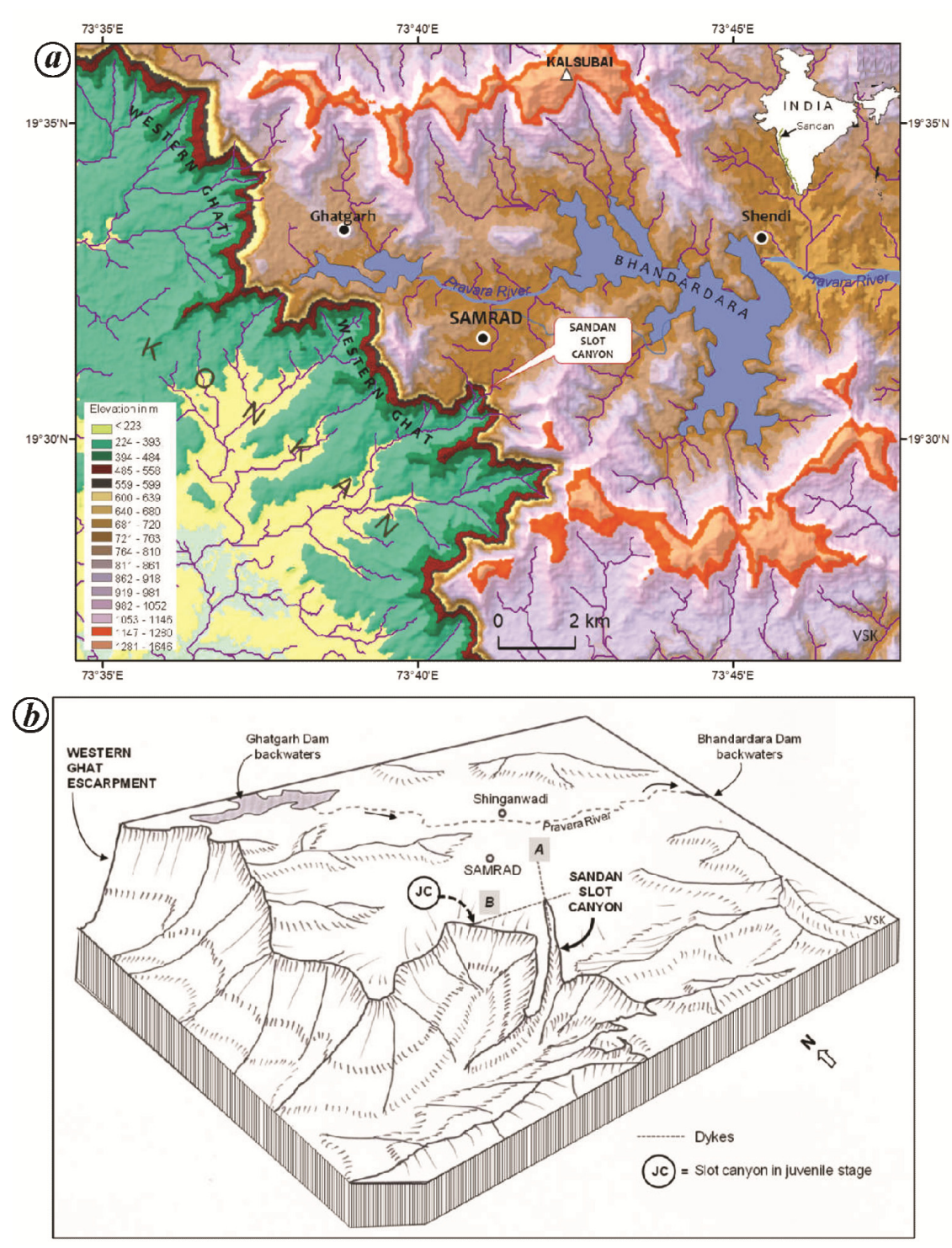

Figure 1. $\boldsymbol{a}$, Colour-coded elevation map showing the location of the Sandan slot canyon (SSC) on the crest of the Western Ghats. The westward-flowing unnamed stream draining the SSC forms a part of the Ulhas River drainage. Kalsubai $(1646 \mathrm{~m}$ amsl) is the highest peak in the Deccan Traps. $\boldsymbol{b}$, Block diagram showing geomorphic setting of the SSC (not to scale). The locations of the two major dykes (A and B) mentioned in the text and the slot canyon in juvenile stage (JC), (locally known as Chornali) are also shown.

(b) to understand the mode of its formation. Geomorphic studies included field observations during multiple visits, and measurement of canyon dimensions and the nature of bed sediments. Seven morphological characteristics emerge from the field studies.

- The over $1 \mathrm{~km}$ long canyon is remarkably linear, with almost vertical to overhanging canyon walls (Figure 2).

- The canyon is 2-30 m wide and 5-95 m deep, and the width-to-depth ratio is unusually small (between 0.10 and 0.35) (Figure 3).

- There is no evidence of a well-defined stream course at the canyon bottom, although a small, westward- flowing (towards Konkan) unnamed stream entering into the canyon is shown on the Survey of India (SoI) topographic map.

- The canyon bed is almost completely covered by small to giant angular boulders (1-9 $\mathrm{m}$ in general and some up to $15 \mathrm{~m}$ in length) (Figure 4).

- The bed is remarkably steep (average gradient= $0.10095 \mathrm{~m} / \mathrm{m}$ ) and due to the presence of very coarse bed material, the bed profile is characterized by multiple breaks with boulder berms (bars) and pools.

- A nearly 3-4 m wide north-south dolerite dyke (dykeA) with crude columnar joints, occurs at the beginning of the canyon aligned in the same direction as the latter. Another nearly perpendicular (WSW-ENE) 


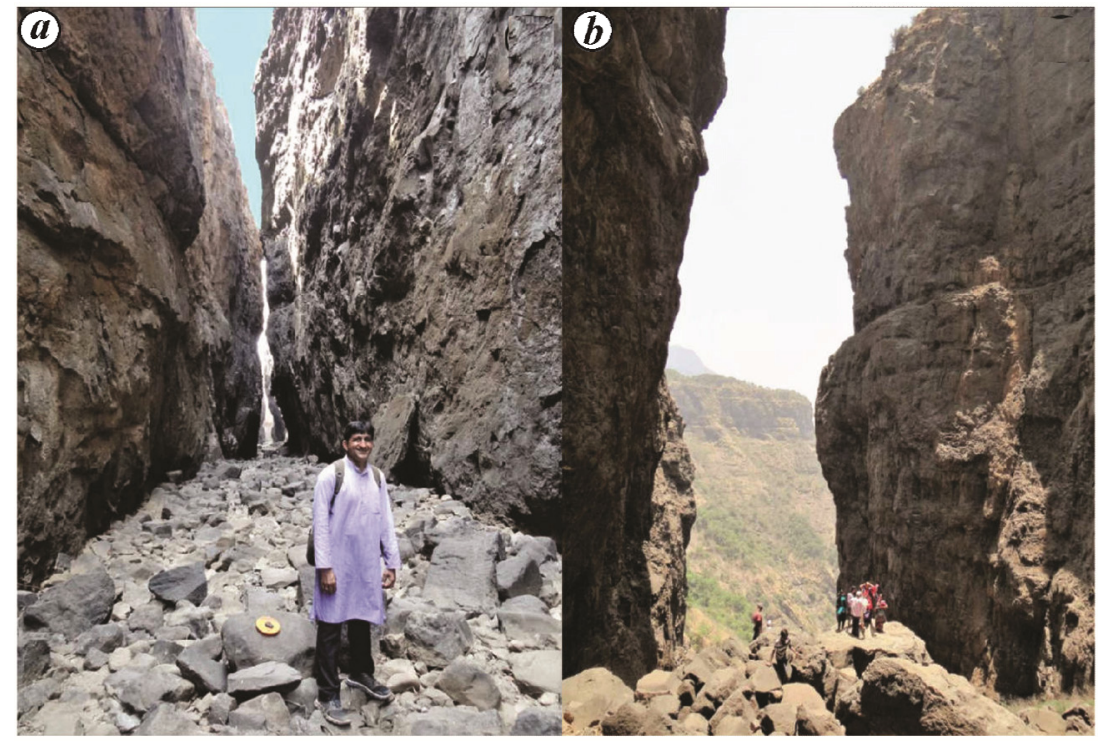

Figure 2. $\boldsymbol{a}$, A view of the extremely narrow SSC floored by angular boulders ${ }^{5}$. $\boldsymbol{b}$, Photograph of the wider canyon at the southern end occupied by giant boulders contributed by rockfall ${ }^{5}$. The Western Ghats Escarpment is visible at a distance. The rocks exposed on the canyon walls are amygdaloidal compound lava flows belonging to the Thakurvadi Formation of the Kalsubai subgroup.

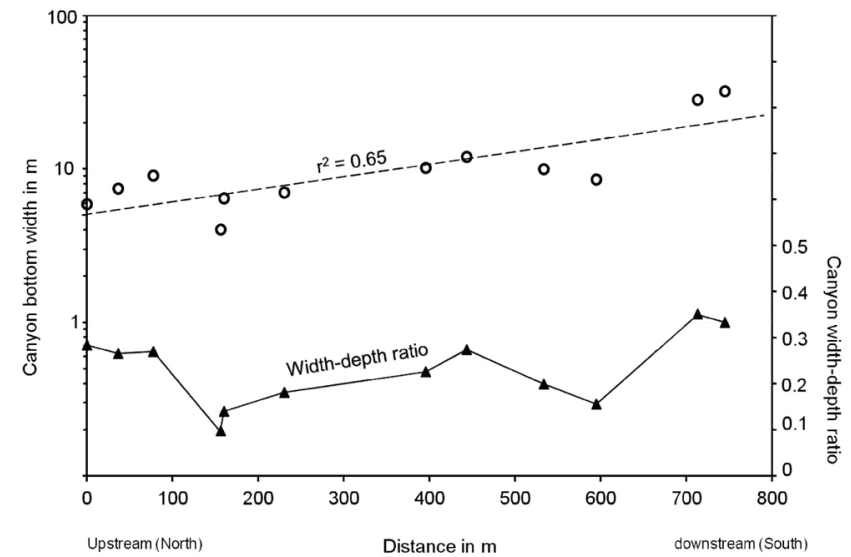

Figure 3. Plot showing downstream variation in the slot canyon width and canyon width-depth ratio. The dashed line is an exponential regression line. The high explained variance $\left(r^{2}\right)$ indicates that the change in width with distance is not completely random. This implies excavation of dyke-A by headward erosion, and excavation has been the main mechanism of fluvial erosion and longitudinal extension of the slot canyon.

oriented dolerite dyke (dyke-B) crosses the canyon at its starting point (Figure $1 \mathrm{~b}$ ).

- Patches of dyke-A are present on both the canyon walls at multiple locations and at different elevations above the canyon bottom (Figure 5).

Spectacular slot canyons, typically formed in crossbedded sandstones are reported from other parts of the world (mainly USA and China). They display remarkably smooth and undulating canyon walls, formed by the fusion of multiple potholes of various dimensions ${ }^{2,3}$. In all but a few cases, sandy sediments dominate the channel bed. Earlier workers have inferred that the wall undulations are remnants of breached potholes or of sinuous longitudinal grooves formed by abrasion during bedrock incision $^{2,6}$. No such evidence exists on the walls of SSC. In fact, the canyon walls here are remarkably rough, uneven and irregular, and there is complete absence of potholes or remnants of potholes in the entire canyon reach. Moreover, small to giant angular boulders cover the bed. All these facts strongly suggest a completely different mode of origin of the SSC.

Clues to the probable mode of origin of SSC are provided by the alignment and extraordinary linearity of the canyon (clearly seen on the SoI topographic map and satellite image of the area), the presence of patches of dolerite dyke at multiple locations on both the canyon walls, and the dominance of coarse angular debris on the bed. It is clear from the size, angularity and lithology of the boulders that they are not fluvially (long) transported, but are fallen blocks of basalt rock from the canyon sidewalls. It is evident in the field that majority of the boulders on the bed have been contributed by the unstable canyon walls by frequent slope failures (rockfall).

The absence of remnants of potholes or grooves on the channel walls implies that the normal process of vertical erosion or downcutting via potholes has not contributed to the formation of this canyon. In fact, the presence of remnants of dyke-A at multiple locations on the canyon sidewalls and small blocks of dyke material within the channel bed sediments supports our hypothesis that the SSC has primarily formed by the excavation of the almost north-south-oriented dolerite dyke (dyke-A). It is also 
evident in the field that the erosion mechanism involved in the excavation of the dyke material is predominantly plucking (also known as quarrying and jacking), rather than abrasion. Plucking is recognized as the dominant mechanism of erosion in rocks characterized by distinct blocks delineated by joints and other structural features $^{1,7}$. The plucking process removes blocks of rocks from the channel boundary (bed and banks) by lift and drag forces during highly turbulent flows ${ }^{1}$. The remnants of dyke-A seen on the SSC walls display crude columnar jointing (Figure 5). The prominent horizontal joints have clearly favoured the removal of joint-defined dyke blocks by hydraulic forces.

Strong hydraulic forces are generated within the narrow canyon during flash floods following heavy monsoon rainfall in this steep terrain of the Western Ghats. Though the canyon catchment is small (just $1.6 \mathrm{~km}^{2}$ ), it is located on the crest of the Western Ghats and receives abundant monsoon rainfall ( $\sim 500 \mathrm{~mm}$ at Ghatgarh; Figure 1). Such rainfall, confined to the monsoon months (JuneSeptember), occurs in multiple wetspells. As the run-off into the canyon suddenly increases, the water level rises rapidly in the narrow canyon, elevating the hydraulic efficiency and stream power of the flows by several orders of magnitude. According to the current paradigm in fluvial geomorphology, the ability of a stream to erode and transport material is related to the stream power as well as the channel boundary shear stress. As there are numerous difficulties in the estimation of flood discharges and the associated stream power $(\Omega)$, one can get some idea about the flood power in the canyon by calculating the boundary shear stress $(\tau)$ (in $\mathrm{Nm}^{-2}$ ) which is the product of specific weight of water $\left(\gamma=9800 \mathrm{Nm}^{-3}\right)$, hydraulic radius or mean depth $(R)$ and the channel slope $(S)^{8}$

$$
\tau=\gamma R S
$$

According to a local guide, the high flows within the canyon during monsoon may reach a depth of up to $5 \mathrm{~m}$ $\left(\sim 15^{\prime}\right)$ over the pools and a few metres above the boulder bars (berms). Thus, at 5 and $2 \mathrm{~m}$ mean water depth and $0.10095 \mathrm{~m} / \mathrm{m}$ bed slope, the above equation yields boundary shear stress $(\tau)$ of 4950 and $1980 \mathrm{Nm}^{-2}$ respectively. These values are higher by two orders of magnitude than $\tau$ values estimated for high-magnitude floods on large Indian rivers ${ }^{9}$. Extraordinary floods within the canyon create even higher shear stress. Such powerful flash floods in the slot canyon are capable of not only dislodging blocks of jointed rocks from the channel boundary, but also moving large boulders present on the bed contributed by the canyon sidewalls due to rockfall ${ }^{9}$. The accumulations of angular boulders (as bars or berms) at intervals support this inference.

A strong and unequivocal support to the abovementioned hypothesis of SSC formation is provided by a juvenile slot canyon (location JC in Figure $1 b$ ), locally named Chornali in the close vicinity of the SSC. Here another dyke (dyke-B) is in the initial stages of excavation. The geomorphic setting is identical and a canyon similar to the SSC is being formed by removal of the

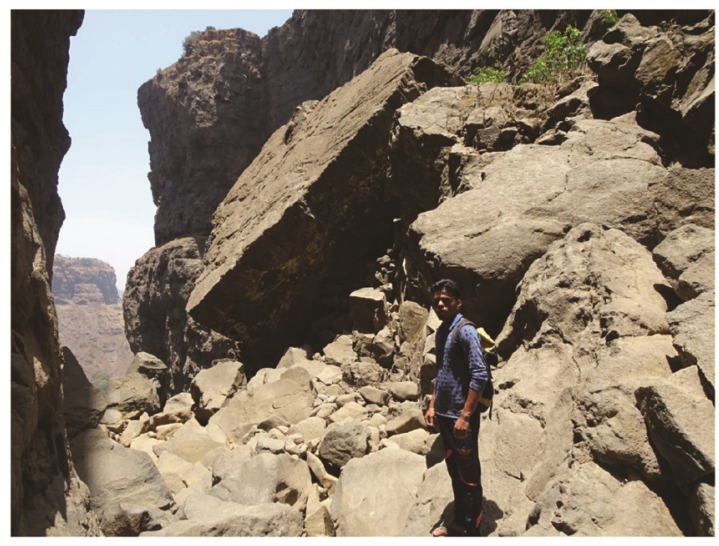

Figure 4. Giant angular boulders (some $>3 \mathrm{~m}$ in length) covering the bed close to the tail end of the slot canyon. These boulders are not made of dyke material but compound lava flows, and were derived from the canyon walls by rockfall.

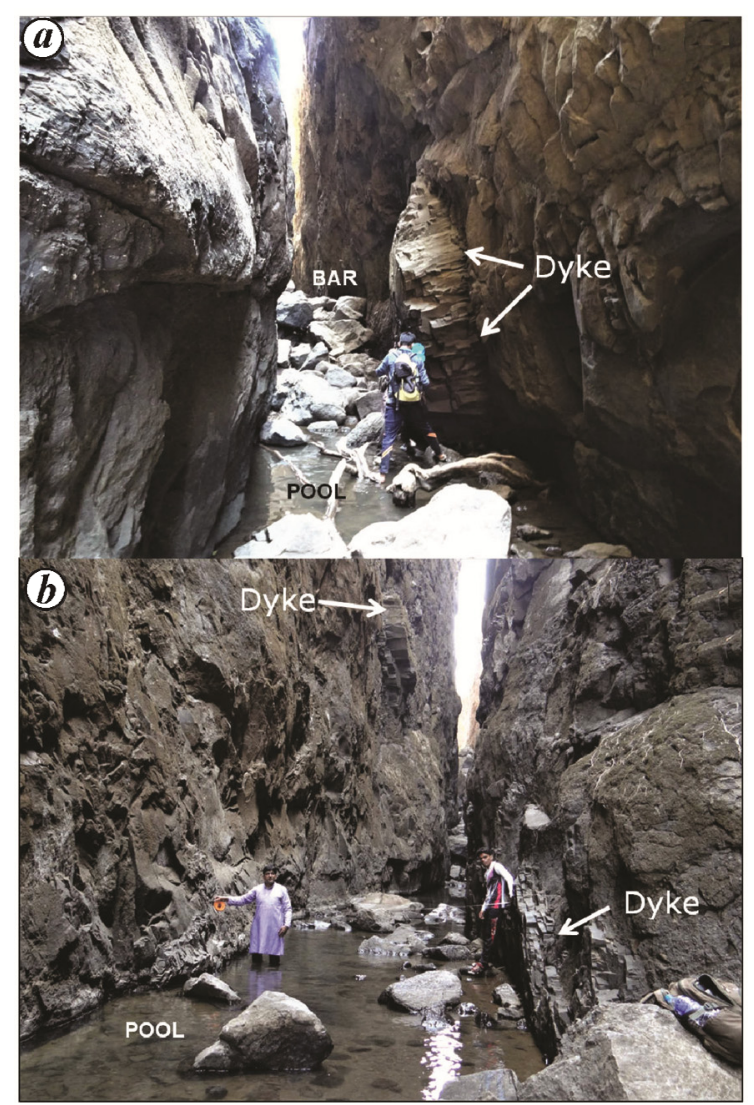

Figure 5. Photographs showing remnants of dyke-A sticking to the canyon walls. Note the crude columnar joints of the dyke. The contact between the compound lava flows and the dyke is clearly visible. Both views looking downstream. $\boldsymbol{a}$, View of the narrowest stretch of the canyon, with a deep pool upstream of a boulder berm (bar). $\boldsymbol{b}$, Remnants of dyke-A on both the canyon walls. 
dyke material. A similar slot canyon is also under formation at Nane Ghat in the source of Kukadi River. Thus, there is little doubt that the SSC has been formed chiefly by the excavation of a dyke. However, the coarse sediments, dominantly made of non-dyke material, on the channel bed suggest that periodic slope failures have contributed in the widening of the canyon after removal of the dyke. This partially explains why the canyon width increases down the valley (Figure 3). Thus, the formation of the slot canyon appears to be a three-stage process. In the first stage, the dyke is excavated on the edge of the Western Ghats Escarpment by hydraulic forces induced by high monsoon run-off forming a very narrow, deep notch. In the second stage, the excavation process propagates upstream along the dyke by headward erosion and excavation, leading to an increase in the length of the canyon. In the next stage, the unstable, exposed, nearvertical walls periodically fail and contribute large rocky blocks to the canyon bottom. This process contributes to the gradual widening of the canyon. The boulders act as an armour and protect the bed from further downcutting (vertical erosion) and excavation. The present shape and morphology of the canyon can be attributed to some extent to this limiting process.

In summary, the SSC is a unique and special geomorphic feature having high scientific as well as touristic value. Not surprisingly, it is already a tourist hot spot and is famous for a host of adventure activities. The present study indicates that the formation of this uncommon slotlike canyon has been determined by a rare combination of site-specific factors - geological, climatic, hydrological and geomorphological. The main inference is that the present canyon morphology is the product of the interplay between flash flood-induced excavation of a dyke and frequent slope failures.

1. Richardson, K. and Carling, P. A., A typology of sculpted forms in open bedrock channels. Geol. Soc. Am. Spec. Pap., 2005, 392, 108.

2. Wohl, E. E., Thompson, D. M. and Miller, A. J., Canyons with undulating walls. Geol. Soc. Am. Bull., 1999, 111, 949-959.

3. Ji, S., Canyons of sculpted rocks: Geographical wonders created by flowing water. Chin. Natl. Geogr., 2018, 693, 135-151.

4. Sanders, D., Wischouniga, L., Gruber, A. and Ostermanna, M., Inner gorge-slot canyon system produced by repeated stream incision (eastern Alps): significance for development of bedrock canyons. Geomorphology, 2014, 214, 465-484.

5. Kale, V. S., Atlas of Geomorphosites of Maharashtra, Indian Institute of Geomorphologists, Allahabad, 2018, p. 76.

6. Carter, C. L. and Anderson, R. S., Fluvial erosion of physically modeled abrasion-dominated slot canyons. Geomorphology, 2006, 81, 87-113.

7. Whipple, K. X., Hancock, G. S. and Anderson, R. S., River incision into bedrock: mechanics and relative efficacy of plucking, abrasion and cavitation. Geol. Soc. Am. Bull., 2000, 112, 490-503.

8. Baker, V. R. and Costa, J. E., Flood power. In Catastrophic Flooding (eds Mayer, L. and Nash, D.), Allen and Unwin, London, UK, 1987, pp. 1-21.

9. Kale, V. S., Geomorphic effects of monsoon floods on Indian rivers. Nat. Hazards, 2003, 28, 65-84.

ACKNOWLEDGEMENTS. We thank Rajendra Gunjal (Department of Geography, KTHM College, Nashik), Uttam Pawar, Gintanjali Bramhankar (Department of Geography, HPT Arts and RYK Science College, Nashik) and the local villagers for their support in the field. We also thank the Editor, Current Science for helpful and constructive suggestions.

Received 24 July 2019; revised accepted 13 August 2019

doi: $10.18520 / \mathrm{cs} / \mathrm{v} 117 / \mathrm{i} 11 / 1892-1896$ 